\title{
How far can one go? How distance matters in island development
}

\author{
Godfrey Baldacchino \\ University of Malta, Malta \\ Godfrey.baldacchino@um.edu.mt
}

\begin{abstract}
Island development trajectories are heavily impacted by their relevance, similarity, complementarity and value in relation to continental development pathways. I would argue that this is so, also because of the physical proximity of islands to their respective metropolis, making the former island units in and of their respective mainland. This paper proposes a politics of distance. It examines how physical detachment from the mainland (and from central government) impacts on an island's ability to determine its own destiny and developmental course. This paper does so by reviewing how near islands and remote islands have: (a) nurtured different levels of jurisdictional status and autonomy; and (b) used that jurisdictional resource, where available, to chart their own development trajectory, in ways that may be similar, complementary, different and outright in opposition to mainland ambitions and plans. In such liaisons, remote islands are more likely to avoid the clutches, overtures and demands of (more distant) powers - and thus depart from mainland agendas - than near islands.
\end{abstract}

Keywords: distance, island studies, jurisdiction, near islands, remote islands

https://doi.org/10.24043/isj.70

C 2019-Institute of Island Studies, University of Prince Edward Island, Canada.

\section{Introduction: profiling island development}

Islands, and small islands in particular, can hardly aspire to a development paradigm which expects them to generate economic growth from their own local assets and factor endowments. The best they can hope for is a suite of "pseudo development strategies" (Baldacchino, 1993), whereby (small) island life is nurtured largely by inflows of cash, resulting from added value elsewhere and typically from the mainland components of their state. Those exogenous variables (Warrington, 1992), often marginalised and considered insignificant in classical economics, are the very lifeline to these small islands and their inhabitants (Adrianto \& Matsuda, 2002; Bertram \& Poirine, 2018).

In such circumstances, can the profile of an island's development differ from that of its mainland? Locked in a dependency relationship, one may well expect that the developmental agendas of small subnational island units are therefore drawn up and dictated by their larger mainland, or main island, components. Hence, in the case of countries that either are or include islands or archipelagos, there is likely to be a relationship between mainland (or main island) and smaller island/s which can be reflected in specific economic and development approaches.

In this paper, we will review if, and the extent to which, the physical distance of an island from its contiguous mainland creates conditions for both self-government as well aspartly in consequence - a development route distinct from mainland blueprints and ambitions. The paper's main thrust is to explore situations where islands will adopt or complement, but also clash or jar with, the development plans proposed by their central 
governments. In such situations, islands may wield the tools of governance at their disposal to (attempt to) block mainland agendas, try and shift them such as to best meet their local interests, or resort to 'damage control'. In this power game, the physical distance between island and mainland may 'load the dice' and influence (but not determine) the outcome.

Since we are dealing with discrete islands, and not necessarily with islands that are in themselves political units, one challenge of such an investigation deals with the absence of official and reliable data (e.g. Armstrong \& Read, 2000). This paper restricts its analysis to island units of larger countries that enjoy a regional and/or juridical identity, enough for them to appear as discrete units in national statistics. Luckily, most islands that are remote from their mainlands are also distinct political, and therefore statistical, units - singly or collectively, as an archipelago - and so, the problem of missing or poor data is not that severe.

The situation is different for near islands, defined here as islands that lie not more than 12 nautical miles $(22 \mathrm{~km}$ ) from the mainland coast (Baldacchino \& Pleijel, 2015). Most have been absorbed into the jurisdiction of their contiguous coastal region (e.g. the Isle of Skye and Lochlash in Scotland, UK, since 1996; Cape Breton Island into the province of Nova Scotia in Canada since 1820; and Ile de Ré as part of the department of Charente-Maritime in France). These and similar islands lack jurisdictional autonomy: there are 27 small island states in the world today, each with a resident population of up to one million; none of these is a near island or archipelago.

\section{Death of distance?}

The globalisation of consumer tastes, the rapid dispersion of information and communication technologies, and the relentless flow of information has led to arguments about the end, or death, of geography. In today's "global village" (McLuhan \& Powers, 1992), there is a definitive compression and convergence of time and space: a consequence of things becoming easier and cheaper to communicate faster (Janelle, 1969, p. 359; Harvey, 1989; Ohmae, 1991). This concept has become a fashionable narrative in business and marketing circles: thanks to improvements in transportation, hyper-mobile finance, footloose capital and media technologies. The actual physical site of things blurs immaterial, so much immigration is circular rather than uni-directional, and even the location of physical customers becomes irrelevant to their ability to receive seamless service from their preferred suppliers (Martin, 1996; Morgan, 2004; O’Brien, 1992).

And yet, the "death of distance" (Cairncross, 1997) has been grossly exaggerated. A place-based, protectionist surge has emerged as an alternative political narrative, confronting the neo-liberal doctrine (Giddens, 2018). Ethno-nationalism has galvanised secessionist politics (Connor, 2018); and place branding seeks to profile specific locations, including islands, for competitive advantage (Baldacchino \& Khamis, 2018; Papadopoulos, 2004).

In this paper, we argue that distance remains a relevant conceptual tool, also in the field of island governance: to the extent that an island's development agenda is significantly determined by the effects of distance from the locus of its central government. We do not advocate any geographical determinism here. Any 'distance-jurisdiction' correlation would be invariably mediated by historical antecedent, administrative practices, political cultures and the personalities, ambitions and strategies of discrete politicians. However, we opine that: (1) physical remoteness suggests that a subnational island unit has more jurisdictional autonomy, in law and in practice, to determine its own future; and (2) that the same jurisdictional arsenal will be deployed in relation to development options that may be suggested or imposed on such islands by their larger island/mainland regimes. The opposite also applies: closeness to the heartland of the country reduces any such 'room for manoeuvre' (Clay \& Schaffer, 1984) for the smaller player - typically the island, although pre-independence Singapore in relation to mainland Malaysia makes a notable exception (Barter, 2007). It also restricts access to the 
governance tools that would be required for the island's citizens and their political representatives to legitimately pursue any development route that is different from that proposed and driven by the central government.

Thus: how far one can go-in terms of a specific, island driven, development agendamay really have something to do with how far one is. There is, as yet, no articulated theory for centrifugal politics in island studies (e.g. LaFlamme, 1983); but this paper may be a useful start. And islands lend themselves as "natural experiments" to such an analysis, given that there are ample examples of both near and remote islands at different distances from mainlands (Diamond \& Robinson, 2010).

\section{Remoteness in island studies}

For those studying islands, it is the natural scientists that are likely to quickly recognise a causal relationship between remoteness and island life. An increasing distance of islands from mainlands, and therefore from the main source of species pools, leads to reduced rates of new species immigrating to the island, impacting on the right-sloping curve of the McArthur and Wilson species-area relationship (McArthur \& Wilson, 1963, 1969/2001).

Biogeographers since Darwin (1859) and Wallace (1880) have hinted at the effect that distance from the mainland can have on island evolution. Continental islands-which tend to be made out of sedimentary rock, hug mainland coastlines and would have been part of the same mainlands prior to processes of erosion, collapse and sea level rise-tend to have a biotic pool not that different from that of their contiguous mainland. In contrast, life on oceanic islands - born out of coralline or volcanic activity, and separated from mainlands by huge tracts of ocean-strikes its own and unique evolutionary path, and typically throws up many examples of endemism (and, subsequently, extinction). The theory of island biogeography is predicated on the use of remoteness-distance from mainland-as one of two fundamental measures, and acts as a proxy for species richness (MacArthur \& Wilson, 1969/2001; Kadmon \& Pulliam, 1993).(The other measure is the size of the land mass, a combination of land area and altitude, which serves as a proxy for the extinction of species.)

Economists have also reviewed the dependency of outlying islands in terms of their continued reliance on trade with their former metropolitan countries (rather than neighbouring states), even though such countries may be located very far away. While this may sound irrational, those island economies whose close political linkages to former colonial powers have survived the transition to the post-colonial era have actually been the ones to experience higher per capita levels of economic prosperity (Bertram, 2004).

But: how does distance, or the lack thereof, impact on governance and the "resourcefulness of jurisdiction" (Baldacchino \& Milne, 2000)? First, there are obvious logistical challenges involved in trying to administer remote islands remotely. It quickly becomes clear that an executive body is needed on site for effective government in such locations. This executive experience of self-determination benefits from "extantism" (Bartmann, 2002): it is often (but not always) sticky and irreversible, and paves the way to claims and requests for even greater autonomy by the island from its mainland (though often stopping short of sovereignty) (Baldacchino, 2010; Prinsen et al., 2017; Rezvani, 2014).

Let us start by identifying various islands that could lend themselves to our analysis. These include: (1) islands that are parts of archipelagic states, starting from basic dyads; and (2) islands that form parts of continental states. We exclude: (1) unitary states that are inhabited but single island units (e.g. Barbados, Cyprus, Iceland, Nauru); (2) landlocked states (e.g. Austria, Botswana, Luxembourg, Mongolia, Nepal, Paraguay); and (3) the many island and coastal states which do not have island units or whose island units do not constitute inclusive and self-contained politically administrative units (municipalities, prefectures, provinces, regions) as with Nigeria and Thailand, but also São Tomé and Príncipe as well as the Seychelles. 


\section{Islands, parts of archipelagos}

When dealing with countries that are made up exclusively of a group of islands, one island typically stands out as the 'mainland'. This may be the most populated island, the island boasting the administrative capital of the country, and/or the island with the main (international) airport and seaport. It does not have to be the island with the largest land area.

Tensions are often pronounced in constitutionally recognised, two-island configurations; as in the case of St Kitts-Nevis, where Nevis actually held a referendum on secession in 1998 which was lost by a mere 200 votes (Premdas, 2001). Or in Antigua and Barbuda, secessionist tendencies have flared when, in the wake of the terrible destruction wrought by Hurricane Irma, the central government has proposed a major private hotel development on Barbuda which would challenge the commonwealth-held land tenure system long practised on that island (Parker, 2017). In the Malta archipelago, the sister island of Gozo enjoys a coordinating ministry but otherwise lacks jurisdiction. It had two Gozo-based political parties contest national elections only once, in 1947. A proposed tunnel, linking the two islands, could resolutely snuff out any aspirations for some kind of formalised autonomy (Baldacchino, 2007; Martin, 2018).

Beyond dyads, secessionist tendencies still lurk. In the four-island Comoros, only a minority of voters on the easternmost island of Mayotte voted for independence from France in 1974. This triggered a series of events that saw Mayotte being excised from the rest of the Comoros and becoming incorporated into the French state as its $101^{\text {st }}$ département (Muller, 2012). In Cape Verde, "the political dominance of Santiago [the largest of ten inhabited islands] is occasionally contested by the other islands, especially São Vicente, which is the historic cultural centre of this archipelago" (Corbett \& Veenendaal, 2018, p. 135).

In multi-island units, the inhabitants of smaller islands may "harbour resentment": consider Savaii and Upolu in Samoa; or the outer islands of Tongatapu and Vava'u in Tonga; or Efate, Santo and Tanna in Vanuatu (Corbett \& Veenendaal, 2018, p. 137). In the period immediately after its independence in 1980, Vanuatu required a military intervention to quash a separatist movement on Tanna (Lindstrom, 1981).

Not all archipelagos are small island states. Still in the Pacific, we find Japan, the world's second most populated archipelagic state (after Indonesia). Its largest island, Honshu, at $228,000 \mathrm{~km}^{2}$, is the world's second most populated island (after Java, also in Indonesia). It is the home of the capital city (Tokyo) and Japan's main international airports (Haneda, Narita, Osaka) and seaport (Yokohama). Close to 100 million people live here. Japan claims to have 6,852 islands, of which 421 are inhabited. It has however only one recognised island prefecture out of 47: Okinawa, itself consisting of dozens of small islands, and with the main island, also called Okinawa, with $1,210 \mathrm{~km}^{2}$, having 1.3 million inhabitants.

The Philippines (population: 101 million; land area: 300,000 $\mathrm{km}^{2}$ ) is the world's third largest archipelagic state. Mindanao (population: 25.5 million; land area: $97,500 \mathrm{~km}^{2}$ ) is the country's second largest island and farthest removed geographically from the metropolitan capital of Manila. The island and its outliers has a substantial Muslim population, and militant groups have been fighting for secession. An Autonomous Region in Muslim Mindanao governs the most remote five of the island's 22 provinces. It is the only region in the Philippines that has its own government (Ferrer, 2012).

\section{Islands, parts of continental states}

Let us now turn to islands that form parts of countries that have a mainland, continental component. Starting with Italy, a European country of some 60 million people, with just over $10 \%$ of its population living on islands: mainly on Sicily $-25,700 \mathrm{~km}^{2}$, the largest island in the Mediterranean Sea, and with the largest island population in that sea, at 5.1 million- 
and Sardinia-24,100 $\mathrm{km}^{2}$, the second largest island in the Mediterranean, and with the second largest island population in that sea, at 1.65 million.

Still in Europe, we find Greece, a country with a population of around 11.2 million, of which $90 \%$ live on the mainland ( 3 million in Greater Athens alone). Of the country's nine geographical regions, three deal only with islands: the Ionian cluster; the Aegean cluster, and the island of Crete. At $8,300 \mathrm{~km}^{2}$, Crete is Greece's largest island, and the fifth largest island in the Mediterranean Sea, with a population of 620,000.

Croatia (population 4.2 million) is another, but smaller, European country with a sizable island component. The total area of the 47 inhabited islands of Croatia is $3,140 \mathrm{~km}^{2}$, or $5.6 \%$ of the total area of the Republic. The total island population is slightly over 100,000 (or just over $2 \%$ of the total Croatian population). With a population of around 19,000, Krk is the Croatian island with the largest population. With a land area of $406 \mathrm{~km}^{2}$, it is both the largest and most populous island in the Adriatic Sea. The island, however, does not comprise its own administrative division: along with Cres Lošinj and Rab, it forms part of the region of Primorje-Gorski Kotar.

Next, we visit France (land area: 644,000 km²; population: 67 million), and its current 101 departments (or administrative regions). Of these, the very distant islands of Guadeloupe, Martinique, and Réunion have been departments since 1946; and the island of Mayotte since 2011. The closer island of Corsica, with a land area of $8,680 \mathrm{~km}^{2}$, is the fourth largest island in the Mediterranean Sea; and has a population of 330,000. It is back to being one, single department in 2018, after having been divided into two departments since 1975.

Within the United Kingdom (land area: 242,500 km²; population: 65.6 million), only five island local councils do not have mainland attachments: the Isles of Scilly (actually five populated islands; land area of $16 \mathrm{~km}^{2}$; population of 2,300) and the Isle of Wight $\left(384 \mathrm{~km}^{2}\right.$; population of 141,000), both in England; and then the Outer Hebrides $\left(3,059 \mathrm{~km}^{2}\right.$; population of 27,000$)$ Orkney $\left(990 \mathrm{~km}^{2} ; 22,000\right)$ and Shetland $\left(1,466 \mathrm{~km}^{2} ; 23,000\right)$, all in Scotland. Should we consider the British Isles, we would need to add the Channel Islands (Jersey, Guernsey and its dependencies, as well as Alderney and Sark) and the Isle of Man, which are 'crown dependencies' that enjoy a special and unique relationship with the British Crown.

There are fifty states in the United States of America (land area: 9,148,000 $\mathrm{km}^{2}$; population: 330 million); but only the $50^{\text {th }}$, Hawai'i is a fully island state. It is also the only state in the US with a significant and vocal indigenous minority that also harbours secessionist sentiments (Osorio, 2001). By virtue of the 1993 Public Law (103-150), the US Congress formally apologised "for the overthrow and the deprivation of the rights of Native Hawaiians to self-determination" when groups sympathetic to the US deposed Queen Lili'uokalani and the Government of Hawai'i in 1893, and led to its eventual annexation as a US state in 1959.

In Australia, (7,692,000 km²; population: 25 million) the year 2015 marked the "unprecedented recolonization" (Gonshor, 2017) of Norfolk Island $\left(34.6 \mathrm{~km}^{2 ;}\right.$ population: $1,750)$ by its administrative power. The island lost the autonomy it had enjoyed since 1979 and was incorporated into the state of New South Wales. Opposition to the reforms have included an appeal to the United Nations to include the island on its list of 'non-selfgoverning territories' (RNS, 2016) as well as a movement to secede from Australia and join closer New Zealand instead (Roy, 2017).

Turning now to Asia, consider the situation of the Republic of (South) Korea $\left(100,210 \mathrm{~km}^{2}\right.$; population: 51 million). South Korea has some 470 populated islands that have a total population of just over 1 million. However, only one of these islands is a special, selfgoverning province, and is one of the nine provinces of Korea: Jeju $\left(1,800 \mathrm{~km}^{2}\right.$; population: $600,000)$. Jeju is the largest island off the coast of the Korean Peninsula.

Lastly, let us consider the most populous country in the world: China $\left(9,597,000 \mathrm{~km}^{2}\right.$; population: 1.3 billion). The (largely island) territories of Hong Kong (a peninsula plus 263 islands) and Macau are recognised as special administrative regions (SARs); while the island 
of Taiwan $\left(35,800 \mathrm{~km}^{2}\right.$, population: 23.5 million) along with its own dependencies (also islands) is also treated as an SAR, although it is de facto its own jurisdiction since its administrative split with 'mainland China' in 1949. Hainan $\left(35,400 \mathrm{~km}^{2}\right.$; population: 9.2 million) is the only island province of China; it is a special economic zone and a designated free port region. It is strategically well placed to serve as the gateway towards the execution of the $21^{\text {st }}$ century Maritime Silk Road (Blanchard, 2017). The July 2018 inauguration of a direct and non-stop flight by China Southern Airlines from London, UK to Sanya, Hainan, is also indicative of the intent to position the island as an international, visa-free tourist destination. Chongming $\left(1,000 \mathrm{~km}^{2}\right.$; population: 660,000$)$, an alluvial island, is China's third largest, and is connected to the mainland by bridge and tunnel; while Zhoushan $\left(500 \mathrm{~km}^{2}\right.$; population: 1.15 million) is the fourth largest island, located in China's largest archipelago with its 1,390 islands, and has been linked to the mainland with bridges since 2009. Pingtan (population: 450,000; 6,435 $\mathrm{km}^{2}$ ) is China's fifth largest island: a 3-km bridge was built in 2010, connecting it to the mainland. Large areas of the island's coastline have experienced land reclamation, along with large-scale building and infrastructure projects.

\section{Distance, size and jurisdiction}

These random observations of islands that are parts of other, larger jurisdictions, allow us to propose at least three interesting claims.

First, the larger the island's size and population are relative to those of the rest of the country, and the further the island lies from the rest of the country, the more likely is it for that island to enjoy some level of jurisdictional identity and authority. Such jurisdictional status is likely also to be indissoluble, meaning that the whole island-or all the islands of a specific archipelago - is treated as one governing unit: divided islands seem abhorrent and unnatural (Baldacchino, 2013). (One exception here is the Canary Islands of Spain: it consists of two regions, led by Gran Canaria and Tenerife respectively, reflecting a long-standing competition for primacy in the archipelago.) The construction of a fixed link from mainland to island-itself also a function of distance-consolidates and reinforces the island's subservience to mainland tenets of development.

Thus Hainan, just $30 \mathrm{~km}$ away from mainland China, is the 'Hawai' $\mathrm{i}$ of China'; its beaches attract some 60 million continental Chinese annually (Westcott, 2017). As of May 2018, residents of 59 countries have been granted visa-free access to the island, enhancing its appeal as an international tropical island tourism destination $(\mathrm{Li}, 2018)$. At the same time, foreign workers are being encouraged to come and settle in Hainan: the resident population is projected to grow by one million by 2025 (Wang, 2018). A permanent link-probably a tunnel-is meant to connect the island and its capital, Haikou, to the Chinese mainland, to assist Hainan to grow even faster, economically and demographically, in accordance with Beijing's plans (Lin, 2018).

Second, relative distance and size, especially in relation to a largely continental and coastal state, also increase the likelihood that the island contributes significantly to the exclusive economic zone (EEZ) of the country as a whole. It also pushes the maritime boundary of a largely coastal and continental country outwards into the high seas, with the island invariably assuming the status of a conduit to the country's maritime aspirations. Such ambitions could be military, economic, commercial, mercantile, industrial, shipping or fishery related, or a combination of these; but also inspired by environmental or conservationist notions (including becoming beacons or prototypes of environmental sustainability). At the very least, and where no such motivations may yet exist, these islands can still serve as natural 'hot spots' or enclaves for tourism, satisfying continental travellers who can enjoy the island's biota, attractions and hospitality without having to leave their own country. Such islands tend to see population levels that are either stagnant or in decrease, with net out-migration to the mainland. Okinawa, in Japan; and Praslin, in the Seychelles, are useful contemporary and diverse examples of this claim. 
Third, and in contrast, so called "near islands" (Starc, 2020), relatively close to the mainland of their country, also tend to be bridgeable. Sooner or later, they may find themselves connected with a fixed link - a causeway, tunnel or bridge - to the mainland section of their country. Since they are so much more accessible, they are tempting targets for short-term tourists (such as day-trippers) and second home tourism. Such permanent physical connectivity is also symbolic of the development thrust that the island adopts, or is forced to adopt. Most often, such near islands become extensions of the mainland: materially, demographically and metaphorically. Such islands tend to see population increases, with migration from the mainland supplementing, even overwhelming, any native population.

In places like Hong Kong, "fixed links have been continuously expanded and further proposals from the government have been made to connect several outlying islands to create land for future urban development" (Leung et al., 2017, p. 63; see also Hong Kong Development Bureau, 2016). Zhoushan was set up as a National District with the theme of marine economy by China's State Council in 2011; and the archipelago "has undergone a gradual industrial transformation and continually strengthening mainland-island contact" (Yue et al., 2017, p. 48). Zhoushan is now home to China's largest fishery, houses part of the busiest harbour in the world in terms of cargo tonnage (Port of Ningbo-Zhoushan) with a throughput of 1 billion tonnes in 2017 (Maritime Executive, 2018), and has become a free port and major innovation hub as a result of central and provincial government development policy.

Thus, these islands' development is a reflection, extension or prolongation of what unfolds on the adjacent, typically urbanised, territory. In Zhoushan's case, a common language, common ethnicity and a common political party mechanism with the contiguous Chinese mainland makes such conformity easier. The fixed link is both trigger and outcome of this alignment. In such cases, and because of this geographical ambiguity between island and mainland, the island has a much reduced political and jurisdictional clout, if it has any clout at all (Baldacchino, 2017; Baldacchino, \& Pleijel, 2015).

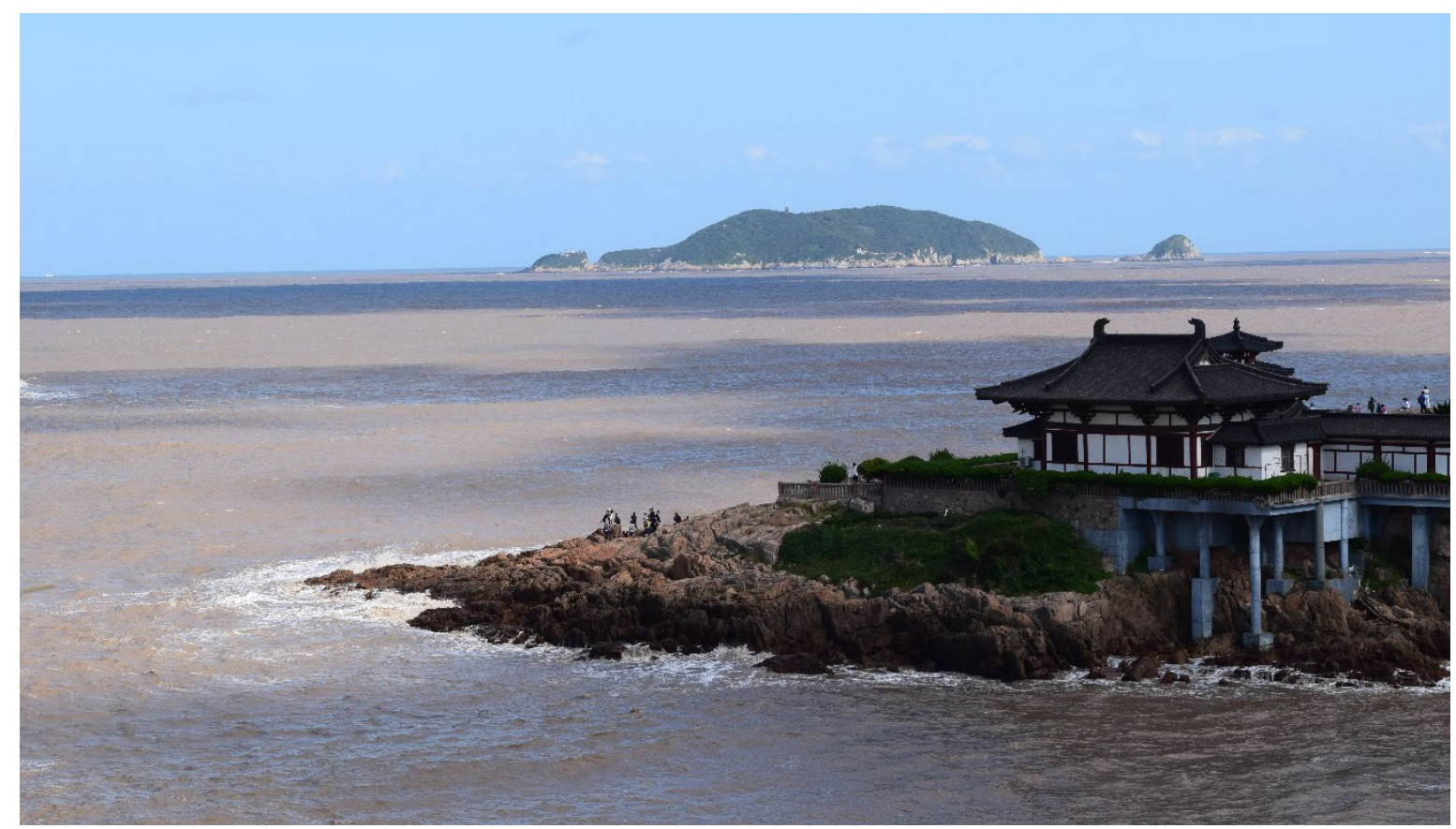

Figure 1: Putuoshan, Zhoushan: The Zhoushan archipelago's close cultural, political, and economic connections with China may foster integration into mainland policymaking processes. Source: Adam Grydehøj, 2018. 
Many of the world's large cities-including Amsterdam, Copenhagen, London, Paris and Stockholm (in Europe) as well as Guangzhou, Jakarta, Manila, Mexico City, Mumbai and Tokyo elsewhere-started off on small 'near islands', including wetlands, marshlands and river deltas, possibly because they were easier to defend in the case of attack. But these eventually spilled over onto their mainlands and incorporated both island and mainland in the course of urban sprawl (Grydehøj, 2015).

In such circumstances, and as this Irish poet laments following the bridge linking mainland Ireland to the island of Valentia, fixed links permit:

islands to become like a landlocked place.

Surrendering their separateness,

to loop with these larger shores,

becoming both part and prisoners of the whole (Murray, 2003).

The trend is statistically significant, as can be discerned from data that relates to European islands. Within the European North Atlantic, there are 252 populated islands. Among these, 139 out of 177 islands that are either coastal or permanently linked to the mainland via tunnel, bridge or causeway have no jurisdiction: each island is not a province or a local government unto itself. In contrast, only 38 out of 75 high seas islands share such a status of non-jurisdiction. Within the Baltic Sea, there are 1,589 populated islands. Among these, 1,478 out of 1,525 islands that are either coastal or linked to the mainland are just local communities: they have no jurisdiction. Only 3\% of coastal islands and $4 \%$ of the bridged islands in the Baltic are municipalities. In contrast, only 49 out of 64 high seas islands have no type of local governance. And in the Mediterranean, there are 284 populated islands. Among these, 105 out of 138 islands that are either coastal or linked to the mainland have no jurisdiction; but only 96 out of 146 high seas islands share such a status. Clearly, and at least in Europe, the distance of an island from its continent exacerbates the tendency, and perhaps the inevitability, of some kind of island self-governance. See Table 1:

Table 1: Relationship between European islands with NO jurisdictional status and their distance from the mainland ( $N=2,125)$. (Baldacchino, 2017; Pleijel, 2013).

\begin{tabular}{|c|c|c|c|}
\hline $\begin{array}{c}\text { European } \\
\text { Island } \\
\text { Region } \\
\end{array}$ & $\begin{array}{l}\text { Bridged and Coastal } \\
\text { Islands: within } 22 \mathrm{~km} \text { of } \\
\text { mainland coast }(\mathrm{N}, \%)\end{array}$ & $\begin{array}{l}\text { Islands on the } \\
\text { High Seas: beyond } 22 \mathrm{~km} \\
\text { of mainland coast }(\mathrm{N}, \%)\end{array}$ & $\begin{array}{c}\text { TOTAL } \\
(\mathbf{N})\end{array}$ \\
\hline North Atlantic & 139 out of $177(78.5 \%)$ & 38 out of $75(51 \%)$ & 252 \\
\hline Baltic & 1,478 out of $1,525(96.9 \%)$ & 49 out of $64(76.6 \%)$ & 1,589 \\
\hline Mediterranean & 105 out of $138(76.1 \%)$ & 96 out of $146(65.8 \%)$ & 284 \\
\hline TOTAL & $\begin{array}{c}1,722 \text { out of } 1,840 \\
(93.6 \%)\end{array}$ & $\begin{array}{c}183 \text { out of } 285 \\
(64.2 \%)\end{array}$ & 2,125 \\
\hline
\end{tabular}

And beyond Europe? Things might have turned out differently for Taiwan $(130 \mathrm{~km}$ from mainland China) since 1949, had it been as close to mainland China as almost equally sized Hainan. But Beijing has not dismissed a tunnel linking it to Taipei, even though it sounds "non-sensical" (Asia Times, 2018).

The list of 119 subnational island jurisdictions compiled by Stuart (2008) contains former colonies, island components of federal states, and islands with a sui generis status resulting from international treaties. In almost all these cases-Canada, being the one notable exception - the islands with these high levels of autonomy sit at the far physical end of the country in question, and as far as one can imagine from the national centre of administration. 
Meanwhile, on the high seas and at greater distance from the mainland, the stakes are higher and the ambitions of the central government bolder. Here, a dynamic relationship unfolds whereby the island may be gifted more powers of autonomy and self-governance by the central state in recognition of its special calling. But the development paradigm proposed by the mainland may not be welcomed by the islanders with open arms; they may even resist it, flexing their jurisdictional powers in the process.

Perhaps we can refer to such mainland-island relations as gravity; not to be thought in terms of its original Newtonian signification as a force of attraction and repulsion; but, rather in its Einsteinian formulation, as a sort of curvature of space-time: body mass curves the fabric of space-time, creating a path that other, smaller entities move along as they fall. The heavier the body -in the sense of this paper, the larger and more populous the island in relation to its mainland-the greater its disposition to craft its own space-time curvature (read: development trajectory).

\section{Tensions between islands and mainlands I: remote islands}

Here are island examples that reflect different modes of secessionism, resistance to mainland ambitions, and the emergence of site-specific political party organisation: all are serious headaches to mainland policymakers.

In Okinawa, US military bases occupy almost one fifth of the island's land area. Mass public demonstrations against the presence, relocation or expansion of the various military bases there continue: one demonstration, in June 2016, was triggered by the death of a 20 year old female resident and linked to a US Marine Veteran, and is claimed to have drawn 65,000 protesters. It is unlikely that the Abe government in Tokyo would want to see US military strength in Japan - financed by Japanese taxpayers - diminished. Yet, demonstrations on land and at sea continue in Okinawa in the face of plans for extending Camp Schuab, a US military base. Takeshi Onega, Okinawa's governor for 2014-2018, had pledged to stop the project (Tanji \& Broudy, 2017).

In Jeju, the South Korean Government has built a military naval base, which was finally opened in 2016, so as to extend its Navy's operational and rapid response capability into the East China Sea. However, many locals have protested, preferring to see their island home as a 'peace island' (Gwon, 2013; Yeo, 2013), an idea rooted in a complex and at times violent history of relations between Jeju and the Korean peninsula.

In the archipelagic Federated State of Micronesia (FSM), the 45,000 citizens of one of its four constituent states, Chuuk, are likely to vote in March 2019 on the possibility of secession from (the rest of the) FSM, and thus hopefully negotiate a compact of free association with the US separately (Sablan, 2018). The "threat of separatism persists" (Corbett \& Veenendaal, 2018, p. 137).

In the United Kingdom, the three fully and exclusively island local councils in Scotland, which are also the most remote from mainland Britain-Western Isles, Orkney and Shetland-capitalised on discussions leading to the run-up to the Scottish independence referendum of 2014. They published a joint mission statement in 2013 signalling that, should Scotland vote for independence one day, they would wish to decide their own future for themselves, while also suggesting that such a future would include devolved powers to the islands for control over seabed resources, marine renewables, fishing and transport (Joint Mission Statement, 2013). In response, the Scottish Executive issued the Lerwick Declaration, setting up a ministerial working group to examine decentralising powers to these three island council areas (BBC News, 2013). The three island councils are the only local authorities among the 32 in Scotland where independent councillors form a majority: tendencies for secession and local self-determination tend to be stronger when island-based political parties are not mere copies or branches of mainland parties (Hepburn \& Baldacchino, 2016). An 
Islands Bill, promoted by the three councils, has been ratified by the Scottish Parliament and became law in July 2018. It was a key aim of the Our Islands, Our Future campaign led by the three local authorities, securing more decision making at a local level and greater economic prosperity for their communities (see Figure 2).

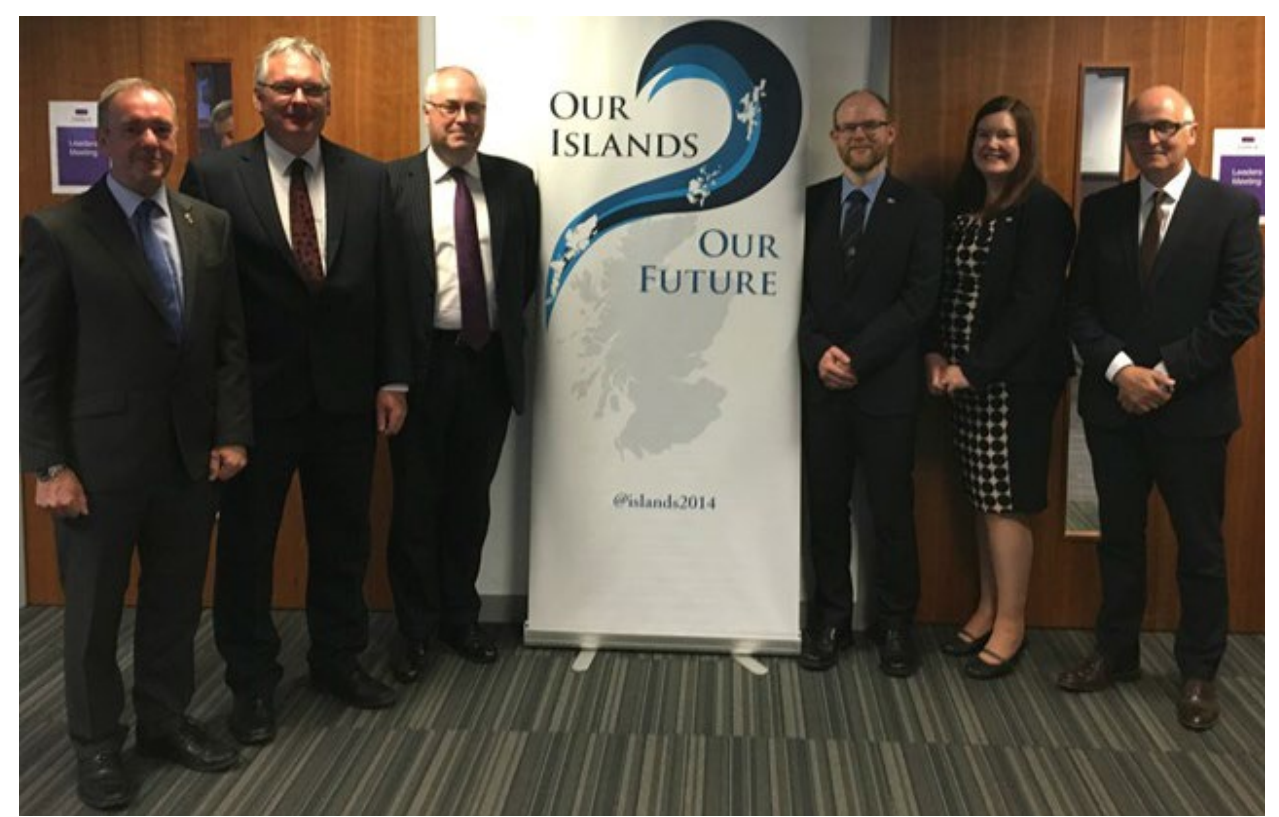

Figure 2: The Leaders and Chief Executives of the Orkney Islands Council, Shetland Islands Council, and Comhairle nan Eilean Siar (Western Isles Council), posing with the Our Islands, Our Future banner. Source: Comhairle nan Eilean Siar (Western Isles Council), 2014. Reproduced with permission.

Something similar has happened when the voters of Corsica elected a regionalist coalition to lead its Assembly in 2015. As a territorial collectivity, Corsica already enjoys a greater degree of autonomy than other French regions; thus, the Corsican Assembly is able to exercise limited executive powers (Fourquet, 2017).

In neighbouring Sardinia, an Italian island province, a suite of island-based ethnoregionalist parties, with no affiliation to parties on the Italian mainland, have also been active in local politics for many years, advancing a non-dependency discourse (e.g. Seddone \& Giovannini, 2014).

On the other side of the world, lies the semi-autonomous and most remote province of Bougainville $\left(9,300 \mathrm{~km}^{2} ; 235,000\right)$ in Papua New Guinea $\left(462,840 \mathrm{~km}^{2} ; 8.1\right.$ million). An independence referendum is expected there in June 2019. This is a direct result of the 2001 Bougainville Peace Agreement which brought a violent civil war to an end (Boege, 2018).

And on the other (western) side of the island of New Guinea lies Papua $\left(319,036 \mathrm{~km}^{2}\right.$; $3,486,000)$ the largest and easternmost province of Indonesia. Since 2002, Papua province has enjoyed a special autonomy status. Such powers may have been granted to stave off secessionist sentiment in the province (Timmer, 2008).

\section{The centre strikes back: island development acts}

The emergence and growth of secessionist sentiments on distant islands may be difficult to prevent. Islanders may be fed up with being notionally part of a larger jurisdiction which however may harbour no sensibility to their specific needs. They may feel abandoned to their fate or neglected by a distant central state that may be busy pandering to areas and constituencies that have many more voters. Where island-specific plans are lacking, such 
islands end up with structural handicaps that could easily see the quality of life of their inhabitants slide. Once this starts to happen, a "cycle of decline" (Royle \& Scott, 1996) can kick in, leading to the exodus of both young people and entrepreneurs, and heralding long term economic and demographic malaise. Moreover, in spite of being often in a clear minority, secessionist or autonomist parties can still smartly and successfully shift mainstream politics to accommodate their aspirations, in part or in full (Baldacchino, 2019).

In such circumstances, granting some measure of self-determination has been a useful antidote. The measure, however, may not necessarily stifle demands for more autonomy: in places like Scotland, it has fuelled even more demands, leading to the Scottish National Party, a pro-independence party, becoming the largest political force in Scotland (Hassan, 2009).

Other measures have involved the central government passing legislation that recognises the peculiarities of (especially remote) islands and thus providing the legal groundwork for specific development policy initiatives, and funding, in their favour.

Japan was the first country to adopt such an approach. The Remote Islands Development Act was enacted in 1953, ushering the first of ten-year development plans, with the aim of "eliminating backwardness" and "rectifying gaps caused by their isolation or remoteness from the mainland" of such remote islands. This was done by implementing major public work projects to improve road and sea connectivity, information and communication technology, industry and national land conservation. This focus has shifted of late: there is now a greater effort towards environmental protection, with many remote islands becoming better appreciated for their natural qualities (including rich culture and biodiversity). Since 2002, there is also recognition that remote islands are important to Japan in order to secure and protect national territory (Kuwahara, 2012).

In Finland, the Island Development Act came into force in 1981. It obliges all authorities to take note of the special status of islands, and so, for example, extending additional support to secure the provision of basic services, suitable island-mainland and island-island transport, and agriculture.

In the Bahamas, the Family Island Development Encouragement Act came into force in 2008. It provides duty concessions on the importation of building materials, equipment and supplies for commercial and/or residential developments on specified 'Family Islands' (Government of the Bahamas, 2018).

Croatia is the most recent country to pass an 'island development act'. The Croatian Island Act, originally enacted in 1999, has been significantly amended and was adopted by Parliament in November 2018 (Starc, 2018).

The European Union similarly recognises its nine 'outermost regions', eight of which are islands, "located thousands of kilometres from continental Europe." These regions are acknowledged as having to deal with various challenges arising from their remoteness, but also small size, islandness and economic dependence on very few products; these features are collectively seen to thwart the islands' development potential (European Parliament, 2018).

\section{Tensions between islands and mainlands II: near islands}

For those islands that are located close to the mainland, their geographical proximity often prevents them from taking a different tack to what the continental government proposes. Their destiny is often to be subsumed within the development plans of the political centre, possibly losing identity and jurisdiction in its wake.

In the sprawling capital cities that have been built on islands, a series of civil engineering works have connected former islands into the expanded metropolis. Dredging, land reclamation, bridges, railway and subway stations reinforce the connection. Major population centres of larger islands and archipelagos include Abu Dhabi, Amsterdam, Bruges, Florianópolis, Gothenburg, Lagos, Leiden, Mombasa, Miami Beach, Montreal, Mumbai, St 
Petersburg, Stockholm and Tromsø (Grydehøj, 2014, p. 185). They also include Chongming and Xiamen in China.

Other near islands have, to some degree, resisted the continental onslaught and its homogenising effects. These tactics have included price differentials, gentrification, access tolls, promotion of non-mass eco-tourism, protection of biodiversity, and lobbying against seamless physical connectivity with the respective mainland. Here are a few examples:

On the island of Fårö, off the island municipality of Gotland, in Sweden, residents voted-twice-against a proposal to have a fixed link connecting their island to Gotland (Kållgård, 2007). One has to cross over by ferry. In spite of this, "there are about 250 residential homes on Fårö and over 1,000 summer homes" (Pergament, 2007).

The island of Ré $\left(85 \mathrm{~km}^{2}\right.$; population 18,000$)$ lies very close to the city of La Rochelle (population 80,000), in Western France; its cuisine, landscape and beaches attract thousands of French holidaymakers annually. When a bridge was proposed linking the island to the mainland - at $3 \mathrm{~km}$, the second longest bridge in France - the islanders and those with second homes protested because they expected a massive influx of visitors and day-trippers. The eventual decision was to build the bridge and charge a toll to all vehicle users, with those having an island address benefitting from a discounted rate. Since 2009, those with an island address cross the bridge free of charge, while all others pay a $€ 15$ 'eco tax' which is also meant to inhibit usage. In any case, since the bridge was opened in 1988, the population of Ré has doubled. From attracting 670,000 visitors a year pre-bridge, the island lured 3 million visitors in 2012; and property cost or rental is high (Lichfield, 2008; Barthon, 2008; Mulcahy, 2011).

On Martha's Vineyard (land area: $260 \mathrm{~km}^{2}$; population: 16,000), an island group off Cape Cod, Massachusetts, USA, "the cost of living on the island is $60 \%$ higher than the national average, and housing prices are 96\% higher" (Seccombe, 2017). This renders the island de facto inaccessible as a place of residence except to the very rich.

On the Toronto Islands, in Ontario, Canada-a 15-island archipelago on Lake Ontario, with 250 homes - the residents mounted a long campaign against the Toronto City Council and its plans for demolishing their homes and turning the islands into parkland. A compromise solution has been worked out, whereby Billy Bishop (Toronto City) airport (code: YTZ) has expanded operations (and is the national hub for Porter Airlines), while contained residential, leisure and managed natural spaces have been preserved. The Toronto Islands community is credited as the largest urban car-free settlement in North America, even though it sits very close to the continent's fourth largest urban conurbation (Longley, 2017) (see Figure 3). A pedestrian tunnel linking the airport (and the islands) to the mainland opened in 2015, after previous plans to build a bridge were aborted (Taylor, 2016). 


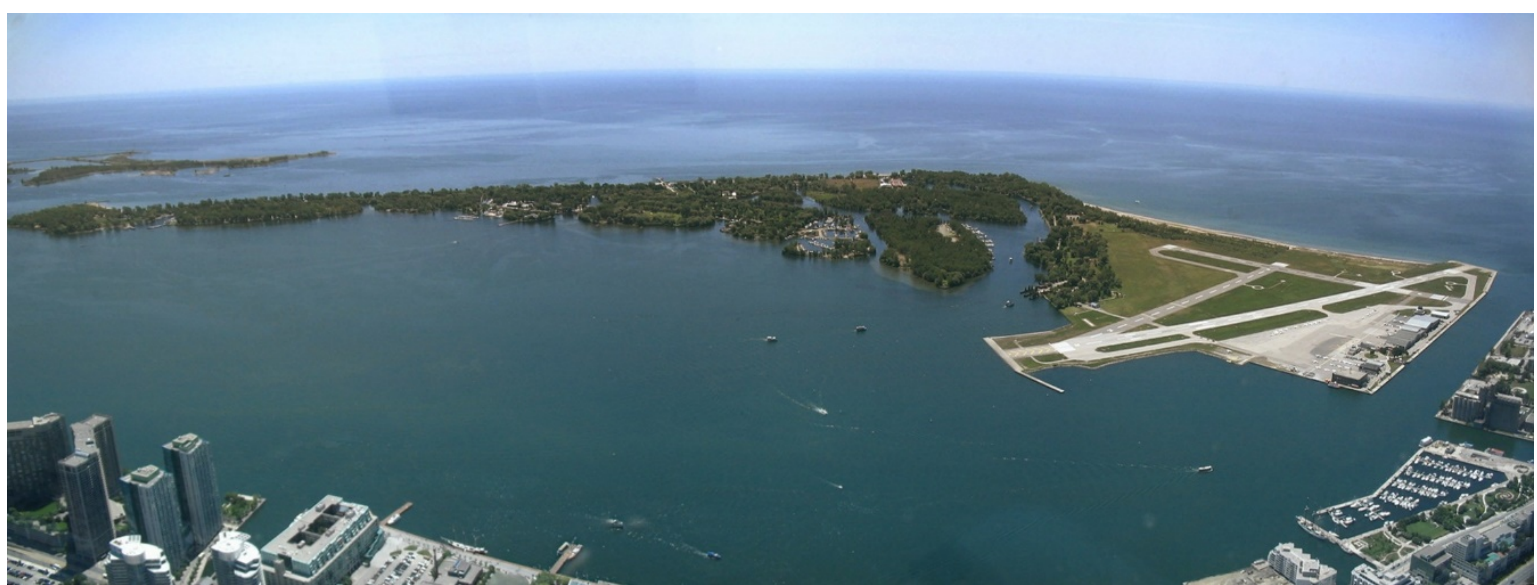

Figure 3: The Toronto Islands, seen from the CN Tower in Toronto: the island community is considered to be the largest urban car-free community in North America, although some service vehicles are permitted. Source: Cmglee, Wikimedia Commons, https://commons.wikimedia.org/wiki/File:Toronto Islands panorama.jpg

There is, thus, some evidence that near islands may function as "enclaves within mainland societies rather than enclaves for mainland societies" (Hong, 2018, my emphasis). They can serve as bulwarks against urbanisation, industrialisation and sweeping homogenisation. And their jurisdictional power, if any, can prove to be a critical resource in securing their distinct development trajectory. This, however, is the exception and not the rule.

\section{Conclusion: distance makes the heart grow fonder}

"In this modern age, remoteness is constituted of just the right mixture of time and space," writes Gillis (2004, p. 153). Perhaps it is time to add a dash of power relations to this combination. With the rich range of degrees of remoteness from mainlands that islands have to offer, the stage is set for an interesting exercise in relational geography, reminiscent also of the dictum that the paradigm, strongest at the centre, is weakest at the periphery (Wallerstein, 1974).

This paper is a modest contribution to the (still early) theorisation dealing with the nature and identity of 'near islands' (or continental islands) versus 'remote islands' (or oceanic islands) beyond the established geophysical distinction between continental and oceanic islands that is now a classic opening staple in island studies texts (e.g. Nunn \& Kumar, 2018). There is a significant difference in the governance capacity of near versus remote islands: this jurisdictional asset of the latter type of island is partly a consequence of the logistic necessity of island-based governance on remote islands; and then becomes its own promoter and motor for further island autonomy and self-determination.

Plans for the endogenous development of remote islands can clash with those hatched by central governments. In such situations, outcomes will depend on power play, bargaining and nervous negotiation. Very often, central governments can still sway remote islands to pursue the development path that the centre has determined through force majeure. In other cases, a complementarity of interests can be sought and found between central and island governments: this is easier when the same political forces and coalitions are involved.

With near islands, the hand of the central government is heavier and closer. The absence of jurisdictional clout facilitates the use of such island spaces by central regimes as extensions of their urban and continental projects, well nested within their gravitational field, often cemented via bridges and tunnels that irrevocably connect and fix such islands to mainlands, and their agendas. Improvements in technology and material science, and the availability of massive funding, will also progressively extend the reach and scope of fixed link infrastructures, 
obliging a shifting definition of what constitutes a near and a remote island-as exemplified by the opening of the Hong Kong-Zhuhai-Macau bridge and tunnel, an impressive $55 \mathrm{~km}$ long structure, linking distant yet metropolitan island centres (Sheng et al., 2017).

Distance, it seems, does more than just make the heart grow fonder. As a Chinese proverb reminds us: "when the mountain is high, the emperor is far away" (Shan Gao Huang Di Yuan in Chinese Pinyin).

\section{Acknowledgements}

I am grateful to the organisers of the conference on Islands, Society, Resources, Tourism held in Zhoushan at the Ocean College campus of Zhejiang University, China, in September 2018, as well as the organisers of the 'Isole' workshop at the University of Cagliari, Sardinia, Italy, October 2018, where this paper served as the basis for my keynote addresses. I am also grateful to Ms Han Chouping (韩 开萍) at the Shanghai University for Traditional Chinese Medicine, for alerting me to the Chinese proverb in the last paragraph.

\section{References}

Adrianto, L., \& Matsuda, Y. (2002). Developing economic vulnerability indices of environmental disasters in small island regions. Environmental Impact Assessment Review, 22(4), 393-414. https://doi.org/10.1016/S0195-9255(02)00012-4

Armstrong, H.W., \& Read, R. (2000). Comparing the economic performance of dependent territories and sovereign micro-states. Economic Development and Cultural Change, 48(2), 285-306. https://doi.org/10.1086/452459

Asia Times (2018). China wants to build a massive underwater tunnel to Taiwan. What could go wrong? The National Interest. 11 April. https://nationalinterest.org/blog/thebuzz/china-wants-build-massive-underwater-tunnel-taiwan-what-25314

Baldacchino, G. (2019). 'Together, but not together, together': the politics of identity in island archipelagos. In Y. Martínez-San Miguel \& M. Stephens (Eds.) Archipelagic thinking: towards new comparative methodologies and disciplinary formations, forthcoming.

Baldacchino, G. (2017). Europe and island tourism. EuropeNow Journal. 6 September. https://www.europenowjournal.org/2017/09/05/europe-and-island-tourism

Baldacchino, G. (Ed.). (2013). The political economy of divided islands: unified geographies, multiple polities. New York: Palgrave Macmillan. https://doi.org/10.1057/9781137023131

Baldacchino, G. (2010). Island enclaves: offshoring strategies, creative governance and subnational island jurisdictions. Montreal: McGill-Queen's University Press.

Baldacchino, G. (2007). Jurisdictional capacity and landscape heritage: a case study of Malta and Gozo. Journal of Mediterranean Studies, 17(1), 95-114.

Baldacchino, G. (1993). Bursting the bubble: the pseudo-development strategies of microstates. Development and Change, 24(1), 29-52. https://doi.org/10.1111/j.14677660.1993.tb00476.x

Baldacchino, G., \& Khamis, S. (2018). Brands and branding. In G. Baldacchino (Ed.) Routledge international handbook of island studies: a world of islands (pp. 368-380). London: Routledge. https://doi.org/10.4324/9781315556642-18

Baldacchino, G., \& Milne, D. (Eds.) (2000). Lessons from the political economy of small islands: the resourcefulness of jurisdiction. Basingstoke: Macmillan. https://doi.org/10.1007/9781-349-62865-0

Baldacchino, G., \& Pleijel, C. (2015). Populated islands of the European Union: a simple matrix and what it tells us. European Small Island Network. https://tikpdf.tips/download/populated-islands-of-the-european-union-a-simple.html 
Barter, P.A. (2007). 'Central' Singapore island; 'peripheral' mainland Johor: making the link. In G. Baldacchino (Ed.) Bridging islands: the impact of fixed links (pp. 261-276). Charlottetown: Acorn.

Barthon, C. (2008). Bridge impacts on islands off the coast of France. In G. Baldacchino (Ed.) Bridging islands: the impact of fixed links, (pp. 219-236). Charlottetown: Acorn.

Bartmann, B. (2002). Meeting the needs of microstate security. The Round Table: Commonwealth Journal of International Affairs,91(365), 361-374. https://doi.org/10.1080/0035853022000010335

BBC News (2013). Scottish ministers to look into extra powers for isles. 25 July. https://www.bbc.co.uk/news/uk-scotland-highlands-islands-23438879

Bertram, G. (2004). On the convergence of small island economies with their metropolitan patrons. World Development, 32(2), 343-364. https://doi.org/10.1016/j.worlddev.2003.08.004

Bertram, G., \& Poirine, B. (2018). Economics and development. In G. Baldacchino (Ed.) Routledge international handbook of island studies: a world of islands (pp. 202-246). London: Routledge. https://doi.org/10.4324/9781315556642-9

Blanchard, J.M.F. (2017). Probing China's Twenty-First-Century Maritime Silk Road Initiative (MSRI): an examination of MSRI narratives. Geopolitics, 22(2), 246-268. https://doi.org/10.1080/14650045.2016.1267147

Boege, V. (2018). Bougainville. The Contemporary Pacific, 30(2), 482-492. https://doi.org/10.1353/cp.2018.0036

Cairncross, F. (1997). The death of distance: how the communications revolution will change our lives. Boston: Harvard Business School Press.

Clay, E.J., \& Schaffer, B. (Eds.). (1984). Room for manoeuvre: an exploration of public policy planning in agricultural and rural development. Plainsboro: Associated University Presses.

Connor, W. (2018). Ethnonationalism: the quest for understanding. Princeton: Princeton University Press. https://doi.org/10.2307/j.ctv39x5s6

Corbett, J., \& Veenendaal, W. (2018). Democracy in small states: persisting against all odds. Oxford: Oxford University Press. https://doi.org/10.1093/oso/9780198796718.001.0001

Darwin, C.R. (1859). On the origin of species by means of natural selection, or the preservation of favoured races in the struggle for life. London: John Murray.

Diamond, J., \& Robinson, J.A. (Eds.). (2010). Natural experiments of history. Cambridge, MA: Harvard University Press.

European Parliament (2018). Fact sheets of the European Union: the outermost regions. http://www.europarl.europa.eu/factsheets/en/sheet/100/outermost-regions-ors-

Ferrer, M.C. (2012). To share or divide power? Minorities in autonomous regions, the case of the autonomous region in Muslim Mindanao. Ethnic and Racial Studies, 35(12), 20972115. https://doi.org/10.1080/01419870.2011.605901

Fourquet, J. (2017). La nouvelle question corse: Nationalisme, clanisme, immigration. La Tour d'Aigues: Editions de l'Aube.

Giddens, A. (2018). Globalisation. In Sociology of globalisation (pp. 19-26). London: Routledge. https://doi.org/10.4324/9780429493089-3

Gillis, J.R. (2004). Islands of the mind: how the human imagination created the Atlantic world. New York: Palgrave Macmillan.

Gonschor, L. (2017). Norfolk island. The Contemporary Pacific, 29(1), 54-165. https://doi.org/10.1353/cp.2017.0011

Government of Finland (2018). Island policy. https://mmm.fi/en/island

Government of the Bahamas (2018). Bahamas Investment Authority . www.bahamas.gov.bs/bia

Grydehøj, A. (2015). Island city formation and urban island studies. Area, 47(4), 429-435. https://doi.org/10.1111/area.12207

Grydehøj, A. (2014). Understanding island cities. Island Studies Journal, 9(2), 183-190. 
Gwon, G. (2013). Remembering 4/3 and resisting the remilitarisation of Jeju: building an international peace movement. In D. Broudy, P. Simpson \& M. Arakaki (Eds.) Under occupation: Resistance and struggle in a militarised Asia-Pacific (pp. 238-270). Newcastle: Cambridge Scholars.

Harvey, D. (1989). The condition of postmodernity. Oxford: Blackwell.

Hassan, G. (Ed.) (2009). Modern SNP: from protest to power. Edinburgh: Edinburgh University Press. https://doi.org/10.3366/edinburgh/9780748639908.001.0001

Hepburn, E., \& Baldacchino, G. (Eds.) (2016). Independence movements in subnational island jurisdictions. London: Routledge. https://doi.org/10.4324/9781315541228

Hong, G. (2018). Islands of enclavization: eco-cultural island tourism and the relational geographies of near-shore islands. Area, published ahead of print. https://doi.org/10.1111/area.12521

Hong Kong Development Bureau (2016). Towards a planning vision and strategy transcending 2030: Preliminary concepts for the East Lantau metropolis. Hong Kong: Hong Kong Government.

Janelle, D.G. (1969). Spatial reorganization: a model and concept. Annals of the Association of American Geographers, 59(2), 348-364. https://doi.org/10.1111/j.1467-8306.1969.tb00675.x

Joint Mission Statement (2013). Our islands, our future. Constitutional change in Scotland: opportunities for islands areas. Shetland, Orkney, and Comhairle nan Eilean Siar representing the Western Isles. http://www.shetland.gov.uk/OIOF/documents/ourislands-ourfutureJointPositionStatement-17june2013.pdf

Kadmon, R., \& Pulliam, H R. (1993). Island biogeography: effect of geographical isolation on species composition. Ecology, 74(4), 977-981. https://doi.org/10.2307/1940467

Kållgård, A. (2007). Sweden, islands and bridges. In G. Baldacchino (Ed.) Bridging islands: the impact of fixed links (pp. 251-260). Charlottetown: Acorn.

Kuwahara, S. (2012). The development of small islands in Japan: an historical perspective. Journal of Marine and Island Cultures, 1(1), 38-45. https://doi.org/10.1016/j.imic.2012.04.004

LaFlamme, A.G. (1983). The archipelago state as a societal subtype. Current Anthropology, 24(3), 361-362. https://doi.org/10.1086/203006

Leung, A., Tanko, M., Burke, M., \& Shui, C.S. (2017). Bridges, tunnels, and ferries: connectivity, transport, and the future of Hong Kong's outlying islands. Island Studies Journal, 12(2), 61-82. https://doi.org/10.24043/isj.24

Li, J. (2018). Americans can now visit the tropical island of Hainan - known as 'China's Hawaii' without a visa. Business Insider. 26 April. https://www.businessinsider.com/americans-canvisit-the-tropical-chinas-hawaii-without-a-visa-2018-4

Lichfield, J. (2008). A bridge too far? Trouble on Paradise island. 15 August. https://www.independent.co.uk/news/world/europe/a-bridge-too-far-trouble-onparadise-island-897565.html

Lin, R. (2018). China to build $\$ 22$ bn undersea tunnel between Hainan island, mainland. Sino-US.com. 28 August. http://www.sino-us.com/10/16504897166.html

Lindstrom, M. (1981). Cult and culture: American dreams in Vanuatu. Pacific Studies, 4(2), 101-123.

Longley, R. (2017). Tempestuous isle: a tragic history of Toronto Islands. Now Magazine. 14 September. https://nowtoronto.com/news/tempestuous-isle/

MacArthur, R.H., \& Wilson, E.O. (2001). The theory of island biogeography. Princeton: Princeton University Press. https://doi.org/10.1515/9781400881376

MacArthur, R.H., \& Wilson, E.O. (1963). An equilibrium theory of insular zoogeography. Evolution, 17(4), 373-387. $\quad$ https://doi.org/10.1111/j.1558$\underline{5646.1963 . t b 03295 . x}$

Maritime Executive (2018). Ningbo-Zhoushan record highlights China's growth. Maritime Executive. 24 January. https://www.maritime-executive.com/article/ningbozhoushan-record-highlights-china-s-growth 
Martin, I. (2018). Malta-Gozo tunnel plans should be ready within six months. Times of Malta.

11 December. https://www.timesofmalta.com/articles/view/20181211/local/maltagozo-tunnel-plans-should-be-ready-within-six-months.696473

Martin, P. (1996). The death of geography: localised learning, innovation and uneven development. 22 February. Financial Times.

McLuhan, M., \& Powers, B.R. (1992). The global village: transformations in world life and media in the 21st century. New York: Oxford University Press.

Morgan, K. (2004). The exaggerated death of geography: learning, proximity and territorial innovation systems. Journal of Economic Geography, 4(1), 3-21. https://doi.org/10.1093/jeg/4.1.3

Mulcahy, O. (2011). While away the days on Ile de Re. Irish Times. 18 June. https://www.irishtimes.com/life-and-style/travel/europe/while-away-the-days-onile-de-re-1.600790

Muller, K. (2012). Between Europe and Africa: Mayotte. In R. Adler-Nissen \& U.P. Gad (Eds.) European integration and post-colonial sovereignty games (pp. 187-203). London: Routledge.

Murray, D.S. (2003). Bridge to Valentia. In D.S. Murray, West-Coasters. Ness, Scotland: Cuan Ard.

Nunn, P.D., \& Kumar, R. (2018). Island origins and environments. In G. Baldacchino (Ed.) The Routledge international handbook of island studies: a world of islands (pp. 52-71). London: Routledge. https://doi.org/10.4324/9781315556642-3

O'Brien, R. (1992). Global financial integration: the end of geography. London: Royal Institute of International Affairs.

Ohmae, K. (1991). The borderless world: power and strategy in the interlinked economy. New York: Harper Perennial.

Osorio, J.K.O. (2001). 'What kine Hawaiian are you?': a mo'olelo about nationhood, race, history and the contemporary sovereignty movement in Hawai'i. The Contemporary Pacific, 13(2), 359-379. https://doi.org/10.1353/cp.2001.0064

Papadopoulos, N. (2004). Place branding: evolution, meaning and implications. Place Branding, 1(1), 36-49. https://doi.org/10.1057/palgrave.pb.5990003

Parker, B. (2017). Barbuda: hurricane-hit paradise for sale? IRIN News. 11 October. https://www.irinnews.org/investigations/2017/10/11/barbuda-hurricane-hit-paradise-sale

Pergament, D. (2007). The enchanted island that Bergman called home. New York Times. 7 October. https://www.nytimes.com/2007/10/07/travel/07cultured.html

Premdas, R.R. (2001). Identity and secession in a small island state: Nevis. Canadian Review of Studies in Nationalism, 28(1-2), 27-44.

Prinsen, G., Lafoy, Y., \& Migozzi, J. (2017). Showcasing the sovereignty of non-selfgoverning islands: New Caledonia. Asia Pacific Viewpoint, 58(3), 331-346. https://doi.org/10.1111/apv.12151

Rezvani, D. (2014). Surpassing the sovereign state: the wealth, self-rule and security advantages of partially independent territories. Oxford: Oxford University Press. https://doi.org/10.1093/acprof:oso/9780199688494.001.0001

RNZ (2016). Norfolk Islanders seeking UN oversight. Radio New Zealand. 28 April. https://www.radionz.co.nz/international/pacific-news/302552/norfolk-islandersseeking-un-oversight

Roy, E.A. (2017). Norfolk Island should become part of New Zealand, says former chief minister. The Guardian. 23 August. https://www.theguardian.com/australianews/2017/aug/23/norfolk-island-should-become-part-of-new-zealand-says-formerchief-minister

Royle, S.A., \& Scott, D. (1996). Accessibility and the Irish islands. Geography, 81(2), 111-119.

Seddone, A., \& Giovannini, A. (2014). Neverland: Sardinia and the independence project of ProgReS. Paper presented at PSA 64th Annual International Conference, Manchester. 
https://www.psa.ac.uk/sites/default/files/conference/papers/2014/PSA-ProgReSGiovanniniSeddone.pdf

Sheng, N., Tang, U.W., \& Grydehoj, A. (2017). Urban morphology and urban fragmentation in Macau, China: island city development in the Pearl River Delta megacity region. Island Studies Journal, 12(2), 199-213. https://doi.org/10.24043/isj.25

Starc, N. (2020). Near islands: a study of the islands of Croatia. Lanham: Rowman and Littlefield International, forthcoming.

Starc, N. (2018). Legalizing islandness. ISISA Newsletter (pp. 10-12). International Small Islands Studies Association. http://www.isisa.org/userfiles/ISISANewsletterJuly2018.pdf

Tanji, M., \& Broudy, D. (2017). Okinawa under occupation: McDonaldization and resistance to neoliberal propaganda. Singapore: Springer. https://doi.org/10.1007/978-981-10-5598-0

Taylor, B. (2016). Once upon a city: the turbulent history of Toronto's island airport. The Toronto Star. 31 January. https://www.thestar.com/yourtoronto/once-upon-a-cityarchives/2016/01/31/once-upon-a-city-the-turbulent-history-of-torontos-islandairport.html

Timmer, J. (2008). Spectres of Indonesianisation and secession in Papua. In Papers presented at the Seminar on the act of free choice (pp. 23-38). The Hague: Institute of Netherlands History.

Sablan, J. (2018). Outreach scheduled on vote to pursue Chuuk independence. Pacific Daily News. 17 April. https://eu.guampdn.com/story/news/2018/04/16/outreachscheduled-vote-pursue-chuuk-independence/519534002/

Seccombe, M. (2017). Cost of living found shockingly high here. Vineyard Gazette. 5 April. https://vineyardgazette.com/news/2007/04/06/cost-living-found-shockingly-high-here

Stuart, K. (2008). A global listing of subnational island jurisdictions. In G. Baldacchino \& K. Stuart (Eds.) Pulling strings: policy insights for Prince Edward Island from other subnational island jurisdictions (pp. 173-185). Charlottetown: Island Studies Press.

Wallace, A.R. (1880). Island life; or the phenomena and causes of insular faunas and floras: including a revision and attempted solution of the problem of geological climates. London: Macmillan and Company.

Wallerstein, I. (1974). The modern world-system: capitalist agriculture and the origins of the European world-economy in the Sixteenth Century. New York: Academic Press.

Wang, O. (2018). China's 'Hawaii of the East' is looking for 1 million new residents, which is more than the population of Stockholm. Business Insider. 16 May. https://www.businessinsider.com/china-hainan-residency-2018-5

Warrington, E. (1992). Taking account of small scale and insularity in administrative reform strategies: the case of Malta, 1988-90. In R. Baker (Ed.) Public administration in small and island states (pp. 221-232). West Hartford: Kumarian.

Westcott, B. (2017). Hainan: is this where Hawaii meets Dubai? CNN Travel. 20 September. https://edition.cnn.com/travel/article/hainan-china-tourists-hawaii-dubai/index.html

Yeo, A. (2013). A base for (in)security? The Jeju naval base and competing visions of peace on the Korean peninsula. In D. Broudy, P. Simpson. \& M. Arakaki (Eds.) Under occupation: resistance and struggle in a militarised Asia-Pacific, (pp. 228-237). Newcastle-onTyne: Cambridge Scholars.

Yue, W., Qiu, S., Zhang, H., \& Qi, J. (2017). Migratory patterns and population redistribution in China's Zhoushan archipelago in the context of rapid urbanization. Island Studies Journal, 12(2), 45-60. 